Nikola Radovanović ${ }^{1}$

Danijela Matović ${ }^{2}$
JEL: D83; M15; 032

DOI: $10.5937 /$ industrija44-9884

UDC: 005.71

005.32

Short Communication

\title{
Organizational forms and knowledge absorption
}

\author{
Article history: \\ Received: 12 Decembar 2015 \\ Sent for revision: 5 February 2016 \\ Received in revised form: 15 August 2016 \\ Accepted: 20 August 2016 \\ Available online: 8 October 2016
}

Abstract: Managing the entire portion of knowledge in an organization is a challenging task. At the organizational level, there can be enormous quantities of unknown, poorly valued or inefficiently applied knowledge. This is normally followed with the underdeveloped potential or inability of organizations to absorb knowledge from external sources. Facilitation of the efficient internal flow of knowledge within the established communication network may positively affect organizational capacity to absorb or identify, share and subsequently apply knowledge to commercial ends. Based on the evidences that the adoption of different organizational forms affects knowledge flows within an organization, this research analyzed the relationship between common organizational forms and absorptive capacity of organizations. In this paper, we test the hypothesis stating that the organizational structure affects knowledge absorption and exploitation in the organization. The methodology included quantitative and qualitative research method based on a questionnaire, while the data has been statistically analyzed and the hypothesis has been tested with the use of crosstabulation and chi-square tests. The findings suggest that the type of organizational form affects knowledge absorption capacity and that having a less formalized and more flexible structure in an organization increases absorbing and exploiting opportunities of potentially valuable knowledge.

Keywords: knowledge management, absorptive capacity, organizational forms, organizational structure, communication network.

\footnotetext{
${ }^{1}$ Intellectual Property Office of the Republic of Serbia, nradovanovic@zis.gov.rs

${ }^{2}$ Ernst \& Young, Serbia 
Radovanović N., Matović D.: Organizational forms and knowledge absorption

\section{Organizacione forme i apsorpcija znanja}

Apstrakt: Upravljanje obimom znanja u organizaciji predstavlja veliki izazov. $\mathrm{Na}$ organizacionom nivou mogu postojati ogromne količine neprepoznatog, potcenjenog znanja, ili neadekvatno primenjenog znanja. Organizacije zbog toga često imaju nedovoljno razvijen potencijal za apsorpciju znanja iz eksternih izvora. Održavanje efikasnih internih tokova znanja u okviru uspostavljene komunikacione mreže može pozitivno uticati na organizacioni kapacitet za apsorpciju ili identifikaciju, širenje $i$ primenu znanja za komercijalne potrebe. Na osnovu dokaza da različite organizacione forme utiču na tokove znanja u organizaciji, ovo istraživanje se bavilo analizom odnosa između uobičajenih organizacionih formi $i$ apsorpcionog kapaciteta organizacija. $U$ datoj studiji smo testirali hipotezu kojom se tvrdi da organizaciona struktura utiče na apsorpciju $i$ iskorišćavanje znanja $u$ organizaciji. Primenjena metodologija obuhvata kvantitativne i kvalitativne metode istraživanja na bazi upitnika, a podaci su statistički analizirani $i$ hipoteza testirana korišćenjem krostabulacije uz upotrebu chi-square testova. Nalazi sugerišu da tip organizacione forme utiče na kapacitet apsorpcije znanja $i$ da postojanje fleksibilnije organizacione structure sa nižim nivoom formalizacije odnosa povećava mogućnosti apsorpcije $i$ iskorišćavanja potencijalno vrednog znanja.

Ključne reči: upravljanje znanjem, apsorpcioni kapacitet, organizacione forme, organizaciona struktura, komunikaciona mreža.

\section{Introduction}

Knowledge has been largely recognized as an important source of competitive advantage and value creation, and as an indispensable ingredient for the development of the dynamic core competencies. Many researchers have discussed the importance of knowledge as an organizational resource, and the consequent relevance of managing it. Being a dynamic resource by its nature, it is clear that knowledge needs to be nourished and managed carefully. Organizations can possess abundance of knowledge embedded in products, methods, practices, experiences, skills, ideas, etc. However, at the organizational level, there can be vast spaces of unknown, poorly appreciated or applied knowledge that lie hidden and unidentified within organizations (Wellman, 2009). At the same time, relevant knowledge may reside at suppliers, clients, competitors, universities, research laboratories and literature (Escribano, Fosfuri \& Tribo, 2006). Argote, McEvily and Reagans (2003) emphasize external R\&D efforts, other companies' products and processes, end users, inter-organizational networks and other as important external knowledge sources. Taking this into account, it is of utmost 
importance for organizations to develop appropriate tools or shift their culture in the way that they become "knowledge-seekers", with the role of searching for the non-identified valuable knowledge in the environment but also within its boundaries. When directing absorptive capacity towards sources of knowledge, orientation to neither internal nor external knowledge sources should be dominant (Van den Bosch, Volberda \& De Boer, 1999). The effect of the existence of such internally and externally-based knowledge to the achievement of organizational goals is largely influenced by the possibility to retrieve, adopt, transform and implement it (Zahra \& George, 2002). Putting efforts into eliminating the barriers of knowledge flow from the external environment into the organization, but also within the organization itself, as well as the obstacles from utilization of knowledge should result in higher probability of identifying potentially valuable knowledge and increased frequency of successful knowledge retrieval and use. This is supported by Mendez et al. (2015) who suggest that the depth of external knowledge search may improve innovation and firms' profitability when learning processes of absorptive capacity are in place. Also, utilization of knowledge can be achieved by its sharing among co-workers. Establishment of the appropriate culture, facilitation of the suitable leadership directions and selection of the appropriate organizational structure should serve as vehicles for this purpose.

The concept of absorptive capacity has been defined as a potential of individual or organization to identify, assimilate and exploit knowledge (Cohen \& Levinthal, 1989). Existence of such dynamic phenomenon influences knowledge base in an organization by renewing it and enlarging it with the influx of new relevant knowledge. Absorptive capacity may influence the potential of an organization to react to new market conditions, adjustment efforts to new environment and use of information in the competitive race; it may also contribute to the creation of new opportunities for competitiveness, knowledge base strengthening and improved forecasting of future market development (Cohen \& Levinthal, 1990; Teece, Pisano \& Shuen, 1997; Van den Bosch, Volberda \& de Boer, 1999; Zahra \& George, 2002; Tu et al., 2006; Camison \& Fores, 2010). A firm with higher absorptive capabilities possesses better learning abilities and foresees opportunities beyond its horizon (Winkelbach \& Walter, 2015). Many theoreticians in this area divide absorptive capacity into dimensions and components, where dimensions include acquisition, assimilation, transformation and exploitation of knowledge, while absorptive capacity components are prior-related knowledge, communication network, communication climate and knowledge scanning mechanism (Cohen \& Levinthal, 1990; Brown, 1997; Zahra \& George, 2002; Tu et al, 2006).

Prior-related or relevant knowledge represents understanding of job skills, products, technologies, markets and other business relevant factors, 
possessed by the workers and managers in the organization (Brown, 1997). It is made of facts and ideas that can influence the process of implementing innovation. Cohen and Levinthal $(1990,1994)$ suggested that organizations with an adequate base of prior relevant knowledge have the ability to more efficiently evaluate and utilize outside knowledge and proactively envisage future technological advances, thus improving absorptive capacity. Communications climate is the atmosphere within the organization that defines accepted communication behavior, which may facilitate or hinder the communication processes (Brown, 1997). There are many findings which support the view that the open and supportive climate can improve sharing, diffusion and use of knowledge (e.g. Nevis et al., 1995; Levinson and Asahi, 1995; Thompson et al., 2006; Bolfiková et al., 2010; Radovanović, 2012). The aspect of interaction that takes place among employees is a crucial element of organizational learning (Wellman, 2009). Communications network represents the scope and strength of structural connections that brings flows of information and knowledge to different organizational units (Brown, 1997). Firms require an improved communication network among their employees in order to improve the internal knowledge flows which foster learning (Campo et al., 2008). Effective communication binds the organization and is essential for enhancing absorptive capacity as well as integrating functional units (Cohen and Levinthal, 1990). Finally, absorptive capacity also depends of the organizational capability to capture relevant knowledge and technology, or of its knowledge scanning mechanism (Tu et al., 2006). This is being done by various activities, such as market tracking, benchmarking, research and development, technology assessments and similar. Cohen and Levinthal (1990) stressed the importance of R\&D collaborations for the generation of new knowledge, which often emerges as a byproduct. The findings from the study by Kostopoulos et al. (2011) show that firms' involvement in innovation collaborations with various external parties enriches their knowledge base and develops a better ability to assimilate and exploit external knowledge.

Based on the characteristics of knowledge dynamics in the organization, Zahra and George (2002) constructed the model where the process of knowledge conversion into activities which create competitive advantage consists of the organizational capability to acquire, assimilate, transform and exploit knowledge. These were referred to as the absorptive capacity dimensions. Zahra and George divided absorptive capacity dimensions into potential and realized absorptive capacity, where potential absorptive capacity included acquisition and assimilation of knowledge, while realized absorptive capacity included transformation and exploitation of knowledge. They suggested that the higher balance between these dimensions lead to increased absorptive capacity stability.

The frequency of knowledge absorption affects knowledge flows within an organization. Understanding technological trends and taking advantage of 
emerging opportunities enable company to estimate future market behavior and new demands, and helps in reorganizing resources for future needs. For this purpose, organization needs to adopt such organizational form which will enhance dynamic knowledge flow and enable removal of all visible obstacles that would hinder its sensitivity to external information. Organizational structure should support knowledge entrepreneurship, which has been identified as a knowledge activator for the generation of innovation and entrepreneurial ventures and the creation of new value. In that manner, it encompasses developing links and networks at all levels, developing infrastructure for innovation and entrepreneurship (Levi Jakšić et al., 2011).

This paper aims at offering insights on relations between the knowledge absorption and the common types of organizational forms that companies nurture. Firstly, we reviewed the literature on concepts of absorptive capacity and organizational structure, followed by the analysis of the relationship between different organizational forms and the nature of knowledge dynamics in organizations. We then applied quantitative and qualitative research methods. Finally, the results have been analyzed statistically in order to test the hypothesis stating that the organizational structure affects knowledge absorption and exploitation in the organization. For the purpose of this study, the analysis and results of the study on absorptive capacity constituents in technology and knowledge intensive industries in Serbia by Levi Jakšić, Radovanović and Radojičić (2013) have been used. The absorptive capacity evaluation model constructed by these authors has been applied in this study in order to determine the relationship between the organizational forms and the absorptive capacity level of organizations.

Organizations from technology and knowledge intensive industries have been selected as the target group for this study. In order to identify organizations from technology and knowledge intensive industries, we have used the OECD classification (2005) with four basic groups of industries: 1) high-tech industries, 2) knowledge and innovation based services, 3) research firms, and 4) traditional medium-tech manufacturing (OECD, 2005). According to the OECD, technology and knowledge intensive industries include leading manufacturers of high-technology products, intensive users of high technologies and organizations with relatively highly educated workforce which is considered necessary for the full use of technology innovations (OECD, 2001). The reason behind choosing this target group is that the exchange of knowledge in technology and knowledge intensive sectors can have a huge influence on the evolution of these industries, where the rate of radical product and process innovations in such industries is high, while the $R \& D$ efforts are typically strongly focused on generating radical innovations (Tödtling, Lehner \& Trippl, 2004). Also, these environments provide greater potential for reshaping organizations within their efforts of achieving excellence (Scott, 1981; Morgan, 2007). Finally, knowledge absorption in 
Radovanović N., Matović D.: Organizational forms and knowledge absorption

technology and knowledge intensive industries is critically important for producing innovations.

\section{Organizational forms and knowledge dynamics}

An organizational structure consists of activities such as task allocation, coordination and supervision, which are directed towards the achievement of organizational aims (Pugh, 1990). Organization itself can be structured in many different ways, depending on its goals, adopted culture and various other aspects. The structure of an organization will determine the modes in which it operates and performs. Organizational structure allows the expressed allocation of responsibilities for different functions and processes to different entities such as the branch, department, workgroup and individual. According to Jacobides (2007), organizational structure affects organizational action in two ways: it provides the foundation on which standard operating procedures and routines rest, and it determines which individuals get to participate in which decision-making processes, and thus to what extent their views shape the organization's actions. Insight into organizational structure provides information on directions and, potentially, frequency of knowledge flows, on how to make internal knowledge sharing more effective, while it also contributes to knowledge management and information science literature.

Organizational infrastructure, as a defining framework for roles, responsibilities, authority, focus and control in the organization, should create a favourable organizational context for knowledge absorption. A distinction must be made between the structural (the extent to which an organization's structure facilitates knowledge sharing) and the cultural infrastructures (establishing a knowledge-friendly culture characterized by a positive orientation towards knowledge and creativity). By providing organizational and technical infrastructures, management should facilitate, stimulate, and influence the emergence of social capital, which in turn influences knowledge retrieval, sharing and use.

Despite the fact that there are growing number of proposed hybrid organizational forms, such as the internal network form (Miles and Snow, 1986) or the $\mathrm{N}$-form (Hedlund, 1994), these have not been described in sufficient detail, so we will limit ourselves to three well-studied organizational forms: functional, divisional and matrix, to illustrate proposed relations. Description of these individual organizational forms is given according to Volberda (1998). The functional form is based on a functional grouping of similar activities under major functional managers, a hierarchy of authority which consists of many hierarchical levels with small spans of control, and a degree of management functionalization which may be limited (with no staff 
functions) or high (staff functions with formal authority). The main advantage of the functional form is the efficiency it attains from economies of scale, overheads and skills. The divisional form is based on grouping by productmarket combinations, a limited hierarchy of authority which consists of few hierarchical levels with large spans of control, and a limited management functionalization in the form of some central staff functions. It is assumed that this form is the most appropriate in a dynamic environment with a large number of different product-market combinations that have few knowledge characteristics in common, and of which the life cycle in relatively long. The matrix form is based on a dual grouping of activities, a dual hierarchy of authority which consists of few hierarchical levels, and a high degree of functionalization of management tasks. On account of its high scope and flexibility of knowledge absorption based on possibility to allocated different available means and persons to various projects, the matrix form is deemed appropriate for organizations that function in environments with many new product-market combinations that have relatively short life cycles. Matrix form has also been considered as the most suitable for organizations which are involved in research and development. Chen et al. (2014) suggests that the most suitable structure for R\&D efforts is the one that can provide the strongest alignment with the strategies of alliance, an exploratory environment for radical new products and a strong transfer of common knowledge among external teams. Having this in mind, the most suitable R\&D organization structure is a matrix structure for focused firms (Chen et al, 2014).

There are many findings which support the view that less formalized, project oriented organizational structure type is more favourable than other forms in terms of knowledge processes in an organization. Galbraith stated (1973) that less formal and decentralized coordination of teams allows flexible coordination during task execution and can deal with ad hoc communication and information needs. Teams, groups and similar kinds of horizontal coordination allow high levels of integration (Lawrence \& Lorsch, 1967). They can be composed whenever a need for knowledge sharing arises (Ayas \& Zeniuk, 2001; Grant, 1996; Van den Bosch et al., 1999). In relation to the strength of tying in a network, Wang (2016) stated that an increase in tie strength initially has a positive effect on knowledge creation, while the effect turns into negative after the tie strength reaches a threshold.

Regarding efficiency, scope and flexibility of knowledge absorption, Van den Bosch et al. (1999) assumed that functional form has a high potential for efficiency and a low potential for both scope and flexibility, divisional form has a low potential for both scope and efficiency and a high potential for flexibility, and matrix form has a low potential for efficiency, but a high potential for both scope and flexibility of knowledge absorption. Based on the assumption that both scope and flexibility have a positive influence on the level of absorptive capacity, while efficiency has a negative impact, the impact on absorptive 
capacity has been determined as negative with facilitation of the functional form, moderate with the divisional and positive with the matrix form. Having in mind that knowledge adoption, assimilation and use are related to the organizational capability to retrieve knowledge, it can be assumed that less centralized organizational form, such as matrix, will be more focused on exploring, rather on exploiting knowledge. On the other hand, it can also be assumed that the organizations with divisional structural type should demonstrate greater exploration efforts regarding knowledge than organizations with functional structural type. Findings by Burcharth et al. (2015) show that cultivating absorptive capacity requires a firm to develop characteristics that support experimentation with costly and uncertain endeavors, which is more characteristic for matrix structures. The same authors argued that firms need to foster a conducive organizational environment marked by slack resources, failure-tolerant attitudes, a predisposition to cannibalize current assets or routines, and external openness.

\section{Research methodology}

The aim of the methodology was to determine the relationship between the applied organizational form in organizations from technology and knowledge intensive industries and their absorptive capacity level. In order to analyze the relationship between organizational forms and absorptive capacity, we needed to evaluate the level of absorptive capacity of organizations, based on the absorptive capacity evaluation model given by Levi Jakšić et al. (2013). By applying this model, the absorptive capacity can be evaluated based on the five variables, which are represented by available relevant knowledge, knowledge base exploitation, potential for the external knowledge inflow, knowledge dissemination capacity and innovation capability. The absorptive capacity evaluation model encompasses the mentioned four absorptive capacity dimensions and it is aligned with the division of absorptive capacity into components. A questionnaire was constructed aiming at gathering the data related to the model variables. The set of questions was based on the recommendations by the researchers in this area. The questions related to prior-related knowledge were constructed based on the findings by Kim (2003), Edenius and Borgerson (2003), Wellman (2009), Kumar and Ganesh (2009), and Senapathi (2011); questions related to knowledge scanning followed recommendations by Tu et al. (2006); while questions related to communication climate and network were proposed following findings by Van den Bosch et al., (1999), Wellman (2009) and Gebauer et al. (2012). The questionnaire included name of the interviewed organization, industry in which it operates, data on the elements and items used in the internal computer 
networks for communication and storage (i.e. intranets), data on the scope of intranet use by employees, data on forms of communication with clients, data on the agreements and contracts with external parties, data on the elements of the knowledge management strategy, educational structure of employees, the extent of knowledge sharing and the data on R\&D, innovations and patent applications.

The questionnaire has been distributed to managing directors of 256 organizations from technology and knowledge intensive industries in Serbia. The research has been conducted in 2013 and the response rate was 20.7\%. Distribution of respondents per specific industries was as follows: ICT -14 , civil engineering -13 , research firms/institutions - 12, pharmaceuticalchemical industry -6 , machinery -5 , electronical devices -2 , aircrafts -1 . Following data collection, the absorptive capacity level for each organization was determined by calculating the average score for all absorptive capacity variables, based on the data which the organizations provided. The score for the prior-related knowledge variable was calculated based on the existence of identified knowledge elements in the organization. For example, if an organization responded that it possesses all listed elements, it received the maximum score, which equals 1 . Any missing element reduced the score proportionally. Calculation of scores of other variables has been carried out in the same way. For every "Yes" answer in the questionnaire the organization received a score of 1 , while for "No" it received 0.

In the second step, the average score was calculated based on the sum of scores of all five variables, and this was interpreted as the overall score for absorptive capacity. Based on the overall score, the organizations were put into four groups: with low (scores from 0-0.25 points), medium low (0.26$0.50)$, medium high (0.51-0.75) and high absorptive capacity level (0.76-1).

For the purpose of the analysis, we also collected the data on the organizational structure of the respondents, asking them about the organizational form which prevails in their structure. The organizations were able to select one of three offered structures - functional, divisional and matrix. Each of them was explained in more details in the questionnaire, similar to the explanation given in one of the previous chapters of this paper. As the final step, we used statistical analysis to determine the relationship between the prevailing organizational structure types in the interviewed organizations with the absorptive capacity level.

\section{Results and discussion}

Based on the results, total of $43.4 \%$ of respondents were classified in the group with medium low ACAP (absorptive capacity), $41.5 \%$ of them belonged 
Radovanović N., Matović D.: Organizational forms and knowledge absorption

to the group with medium high ACAP, 9.4\% of respondents were put in the high ACAP level group, while the smallest portion (5.7\%) belonged to the group with low absorptive capacity (see Table no. 1).

Table 1: Classification of respondents per absorptive capacity level

\begin{tabular}{|l|c|}
\hline \multicolumn{1}{|c|}{ ACAP level } & \% of respondents \\
\hline Low & 5.7 \\
\hline Medium low & 43.4 \\
\hline Medium high & 41.5 \\
\hline High & 9.4 \\
\hline
\end{tabular}

Source: authors' calculation

The mean and standard deviation values for the variables based on the applied model are given in the following table.

Table 2: Descriptive statistics of the model variables

\begin{tabular}{|l|l|l|l|l|l|l|l|l|}
\hline \multirow{2}{*}{ Variable } & \multicolumn{2}{|c|}{ Low ACAP level } & \multicolumn{2}{c|}{$\begin{array}{l}\text { Medium low } \\
\text { ACAP level }\end{array}$} & \multicolumn{2}{c|}{$\begin{array}{l}\text { Medium high } \\
\text { ACAP level }\end{array}$} & \multicolumn{2}{c|}{ High ACAP level } \\
\cline { 2 - 9 } & Mean & $\begin{array}{l}\text { Std. } \\
\text { dev. }\end{array}$ & Mean & $\begin{array}{l}\text { Std. } \\
\text { dev. }\end{array}$ & Mean & $\begin{array}{l}\text { Std. } \\
\text { dev. }\end{array}$ & Mean & $\begin{array}{l}\text { Std. } \\
\text { dev. }\end{array}$ \\
\hline ARK & 0.333 & 0.2082 & 0.360 & 0.1030 & 0.568 & 0.1887 & 0.780 & 0.1643 \\
\hline KBE & 0.314 & 0.2493 & 0.501 & 0.2231 & 0.629 & 0.2231 & 0.843 & 0.1604 \\
\hline PEKI & 0.233 & 0.0577 & 0.378 & 0.1413 & 0.568 & 0.1460 & 0.625 & 0.0957 \\
\hline KDC & 0.250 & 0.2500 & 0.434 & 0.2306 & 0.719 & 0.1371 & 0.885 & 0.1140 \\
\hline INC & 0.083 & 0.0707 & 0.440 & 0.1520 & 0.594 & 0.1250 & 0.608 & 0.2703 \\
\hline ACAP & 0.200 & 0.0400 & 0.433 & 0.0767 & 0.624 & 0.0689 & 0.788 & 0.0268 \\
\hline
\end{tabular}

Note: The acronyms ARK, KBE, PEKI, KDC, INC, ACAP denote: available relevant knowledge, knowledge base exploitation, potential for the external knowledge inflow, knowledge dissemination capacity, innovation capability, and absorptive capacity level.

Source: authors' calculation

The results have shown that 36 (accounting for 67,9\%) of the interviewed organizations responded that functional organizational form prevails in their structure, 8 organizations (or $15,1 \%$ ) responded that their structure is mainly divisional, while 9 organizations (or $17 \%$ ) responded that they implement a matrix organizational form. The data has been presented in the following graph. It is worth noting that while shares of industries where organizations with mainly functional and divisional organizational form originate have been 
Radovanović N., Matović D.: Organizational forms and knowledge absorption

more or less equal, most of the respondents with mainly matrix organizational form come from the ICT sector.

Figure 1. Prevailing organizational form in the interviewed organizations

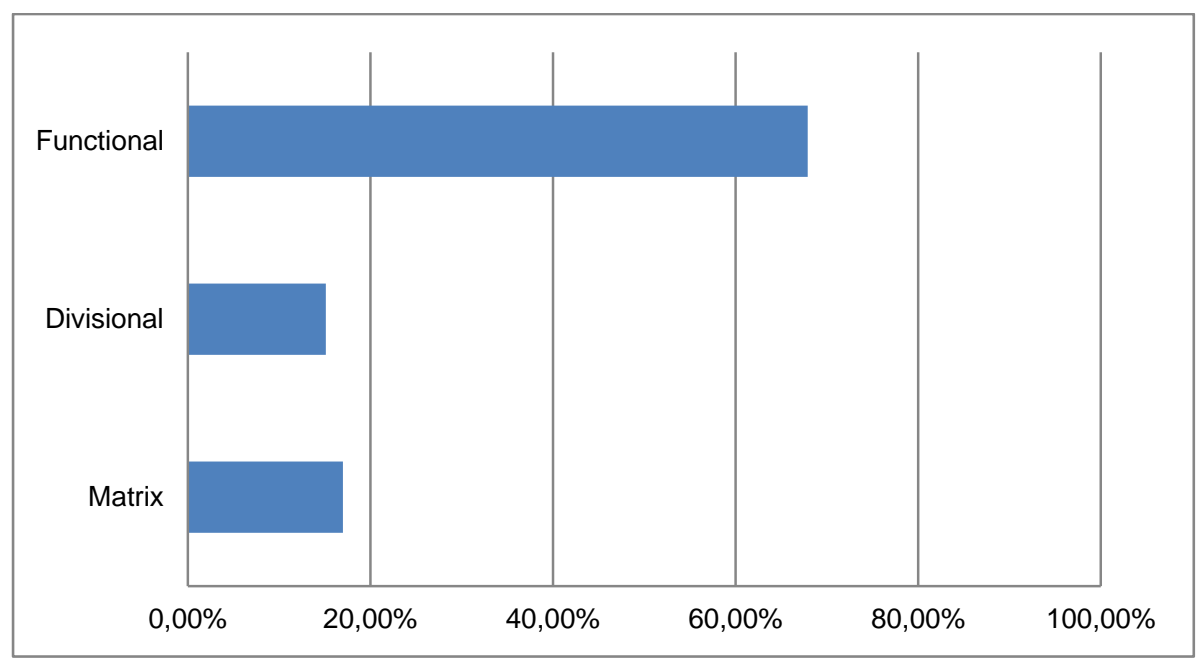

Source: authors' calculation

We then analyzed the relationship between the organizational forms and the level of absorptive capacity. It has been shown that the organizations which implement one of the three standard organizational structure types have different potential in regard to absorptive capacity. Functional organizational form is the most common in the organizations with medium low absorptive capacity level. Divisional organizational form is the most adopted type in the organizations with medium high absorptive capacity level. The rest of the portion of organizations where divisional structure prevails is equally spread among the groups of organizations with medium low and high absorptive capacity level. Matrix form is almost equally spread among groups with medium low, medium high and high absorptive capacity. Finally, neither one organization with matrix or divisional structure recorded low absorptive capacity level.

The received data has been statistically analyzed by cross tabulation with the Chi-Square tests statistical method by using the SPSS software. This was done in order to describe the relationship between the absorptive capacity level and organizational form variables. 
Radovanović N., Matović D.: Organizational forms and knowledge absorption

Table 3: Share of organizational forms per ACAP level

\begin{tabular}{|c|c|c|c|c|c|c|}
\hline \multirow{2}{*}{\multicolumn{2}{|c|}{$\begin{array}{l}\text { Which type of } \\
\text { organizational form } \\
\text { prevails in your } \\
\text { organization? }\end{array}$}} & \multicolumn{4}{|c|}{ ACAP level } & \multirow{3}{*}{$\begin{array}{l}\text { Total } \\
36\end{array}$} \\
\hline & & \multirow{2}{*}{$\begin{array}{r}\text { Low } \\
3 \\
\end{array}$} & \multirow{2}{*}{$\begin{array}{l}\text { Medium } \\
\text { low } \\
20 \\
\end{array}$} & \multirow{2}{*}{$\begin{array}{l}\text { Medium } \\
\text { high } \\
13\end{array}$} & \multirow{2}{*}{$\begin{array}{l}\text { High } \\
\\
0\end{array}$} & \\
\hline Functional & Count & & & & & \\
\hline & $\begin{array}{l}\% \text { within } \\
\text { org.form }\end{array}$ & $8,3 \%$ & $55,6 \%$ & $36,1 \%$ & $0,0 \%$ & $100,0 \%$ \\
\hline & $\begin{array}{l}\% \text { within } \\
\text { ACAP } \\
\text { level }\end{array}$ & $100,0 \%$ & $87,0 \%$ & $56,5 \%$ & $0,0 \%$ & $67,9 \%$ \\
\hline \multirow[t]{3}{*}{ Divisional } & Count & 0 & 1 & 6 & 1 & 8 \\
\hline & $\begin{array}{l}\% \text { within } \\
\text { org.form }\end{array}$ & $0,0 \%$ & $12,5 \%$ & $75,0 \%$ & $12,5 \%$ & $100,0 \%$ \\
\hline & $\begin{array}{l}\text { \% within } \\
\text { ACAP } \\
\text { level }\end{array}$ & $0,0 \%$ & $4,3 \%$ & $26,1 \%$ & $25,0 \%$ & $15,1 \%$ \\
\hline \multirow[t]{3}{*}{ Matrix } & Count & 0 & 2 & 4 & 3 & 9 \\
\hline & $\begin{array}{l}\% \text { within } \\
\text { org.form }\end{array}$ & $0,0 \%$ & $22,2 \%$ & $44,4 \%$ & $33,3 \%$ & $100,0 \%$ \\
\hline & $\begin{array}{l}\% \text { within } \\
\text { ACAP } \\
\text { level }\end{array}$ & $0,0 \%$ & $8,7 \%$ & $17,4 \%$ & $75,0 \%$ & $17,0 \%$ \\
\hline \multirow{3}{*}{ Total } & Count & 3 & 23 & 23 & 4 & 53 \\
\hline & $\begin{array}{l}\% \text { within } \\
\text { org.form }\end{array}$ & $5,7 \%$ & $43,4 \%$ & $43,4 \%$ & $7,5 \%$ & $100,0 \%$ \\
\hline & $\begin{array}{l}\text { \% within } \\
\text { ACAP } \\
\text { level }\end{array}$ & $100,0 \%$ & $100,0 \%$ & $100,0 \%$ & $100,0 \%$ & $100,0 \%$ \\
\hline
\end{tabular}

Source: authors' calculation using SPSS

Table 4. Chi-Square Tests

\begin{tabular}{|l|r|r|rr|}
\hline & \multicolumn{2}{|c|}{ Value } & df & \multicolumn{2}{|c|}{$\begin{array}{l}\text { Asymp. Sig. (2- } \\
\text { sided) }\end{array}$} \\
\hline $\begin{array}{l}\text { Pearson Chi- } \\
\text { Square }\end{array}$ & 18,523 & 6 &, 005 \\
\hline Likelihood Ratio & 18,934 & 6 &, 004 \\
\hline $\begin{array}{l}\text { Linear-by-Linear } \\
\text { Association }\end{array}$ & 12,446 & 1 &, 000 \\
\hline N of Valid Cases & 53 & & \\
\hline
\end{tabular}

Source: authors' calculation using SPSS 
Radovanović N., Matović D.: Organizational forms and knowledge absorption

Based on the likelihood ratio value of 0.004 , we can conclude that the variables are interdependent. Therefore, we assume that the type of organizational structure affects the absorptive capacity level of organizations from technology and knowledge intensive industries in Serbia.

The distribution of organizational forms per absorptive capacity (ACAP) level is graphically presented in the Figure 2 .

Figure 2. Distribution of organizational forms per absorptive capacity level

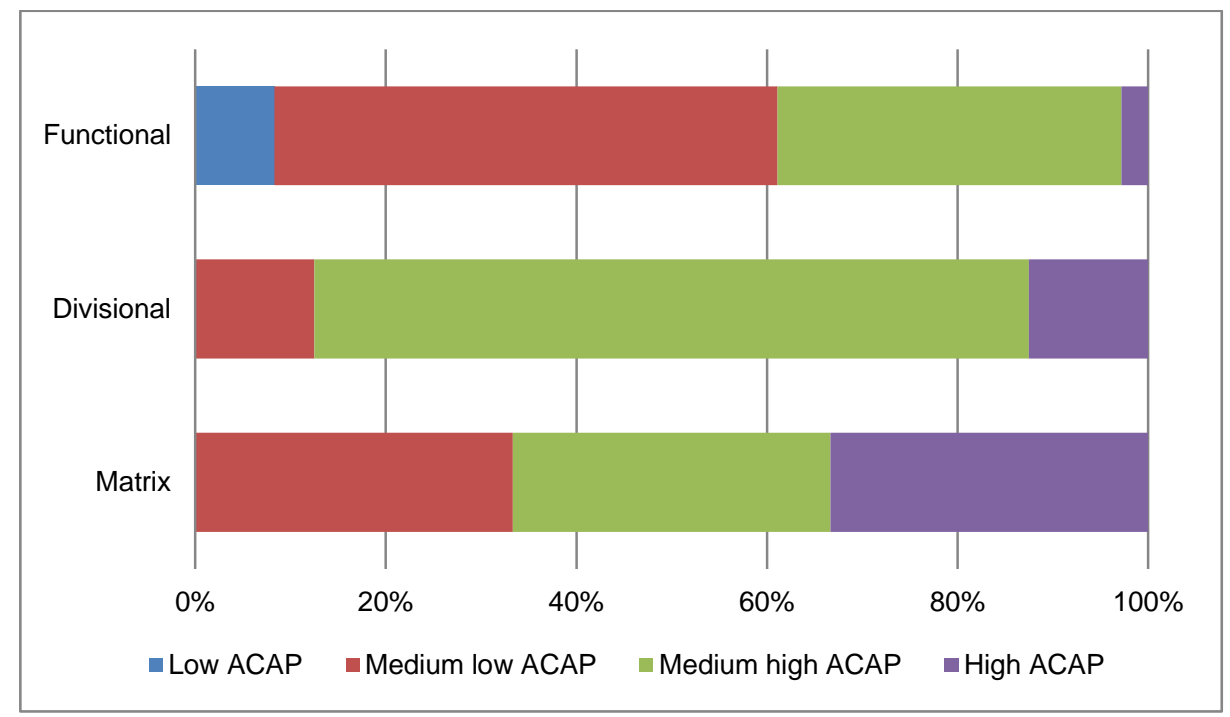

Source: authors' calculation

\section{Conclusions}

This research aimed at showing how typical organizational forms are spread within technology and knowledge intensive industries in Serbia and what are their relations with the absorptive capacity level. It has been shown that the functional form prevails as the organizational structure type in most of organizations. It can be therefore concluded that most organizations continue to employ clearly defined hierarchy and centralized decision making. Characteristics of dynamic markets where companies from technology and knowledge intensive industries perform their activities did not significantly influence management to decrease formalization of activities and increase flexibility in decision-making process and managing individual business units or projects. 
Radovanović N., Matović D.: Organizational forms and knowledge absorption

The statistical analysis supported the hypothesis stating that the organizational structure affects knowledge absorption and exploitation in the organization. The results show that organizations with matrix and divisional structure have higher knowledge absorption potential than organizations which nurture functional organizational structure. This supports the view that organizational forms with low flexibility and strong centralized decision-making system create an environment which slows down the development of the ability to absorb relevant knowledge, while the organizations with lower level of formalization and a project-oriented structure facilitate higher rate of knowledge absorption and use. In can be concluded that increased formalization of activities in the organizations with functional grouping of activities under major functional managers will decrease capacity to absorb and share knowledge. With the aim of creating a favourable organizational context for knowledge absorption, sharing and use, organizations should develop a structure with a high flexibility, lower level of formalization, and a knowledge-friendly culture as a supportive environment for the emergence of social capital.

The results obtained in this study contribute to the organizational theory. The analysis of the relationship between organizational forms and absorptive capacity of organizations studied here provides support to the further development of the knowledge management concept. The results of this research can contribute to the application of different knowledge management strategies within the absorptive capacity framework. Also, the approach undertaken in this study will provide support to the organizational efforts of developing of models for managing absorptive capacity elements.

Limitations to this study include focus on specific industry sectors and analysis of "standard" organizational form types. Only organizations from technology and knowledge intensive industries were studied; hence, results presented here cannot be generalized to all kinds of sectors of industry and environments without further research. Further research may also be directed towards analyzing the relationship between hybrid organizational forms and organizational absorptive capacity and towards developing appropriate management tools for efficient knowledge management within this framework.

\section{References}

Ayas, K., \& Zeniuk, N. (2001). Project-Based Learning: Building Communities of Reflective Practitioners. Management Learning, 32(1), 61-76. doi:10.1177/1350507601321005

Argote, L., Mcevily, B., \& Reagans, R. (2003). Managing Knowledge in Organizations: An Integrative Framework and Review of Emerging Themes. (pp. 571-582). Management Science, 49(4). 
Radovanović N., Matović D.: Organizational forms and knowledge absorption

Bolfiková, E., Hrehová, D., \& Frenová, J. (2010). Manager's decision-making in Organizations-Empirical Analysis of Bureaucratic vs. Learning Approach, Proceedings of Rijeka Faculty of Economics. Journal of Economics and Business, 28(1), 135-163.

Brown, S.A. (1997). Knowledge, communication, and progressive use of information technology. Minneapolis, USA: University of Minnesota. doctoral thesis.

Burcharth, A.L.L.A., Lettl, C., \& Ulhøi, J.P. (2015). Extending organizational antecedents of absorptive capacity: Organizational characteristics that encourage experimentation. Technological Forecasting \& Social Change, 90, 269-284.

Camison, C., \& Fores, B. (2010). Knowledge absorptive capacity: New insights for its conceptualization and measurement. Journal of Business Research, 63, 707715.

Campo, J.D.S.P.G., Gomez, F.G., Dimovski, V., \& Škerlavaj, M. (2008). Exploratory study of organizational learning network within a Spanish high-tech company, Proceedings of Rijeka Faculty of Economics. Journal of Economics and Business, 26(2), 257-277.

Chen, H.H., Qiao, S., \& Lee, A.H.I. (2014). The impacts of different R\&D organizational structures on performance of firms: Perspective of absorptive capacity. Journal of High Technology Management Research, 25, 83-95.

Cohen, W.M., \& Levinthal, D.A. (1994). Fortune favors the prepared firm. Management Science, 40, 227-251.

Cohen, W.M., \& Levinthal, D.A. (1990). Absorptive capacity: A New Perspective on Learning and Innovation. Administrative Science Quarterly, 35(1), 128-152. Special Issue: Technology, Organizations, and Innovation. (March ).

Cohen, W.M., \& Levinthal, D.A. (1989). Innovation and Learning: The Two Faces of R \& D. Economic Journal, 99(397), 569. doi:10.2307/2233763

Edenius, M., \& Borgerson, J. (2003). To manage knowledge by intranet. Journal of Knowledge Management, 75, 124-136.

Escribano, A., Fosfuri, A., \& Tribo, J. (2006). Managing external knowledge flows: The moderating role of absorptive capacity. Research Policy, 38, 96-105.

Galbraith, J.R. (1973). Designing complex organizations. Reading, Mass: AddisonWesley Publishing Company.

Gebauer, H., Worch, H., \& Truffer, B. (2012). Absorptive Capacity, learning processes and combinative capabilities as determinants of strategic innovation. European Management Journal, 30, 57-73.

Grant, R.M. (1996). Toward a knowledge-based theory of the firm. Strategic Management Journal, 17, 109-122. winter special.

Hedlund, G. (1994). A model of knowledge management and the $\mathrm{N}$-form corporation. Strategic Management Journal, 15, 73-90. Summer Special Issue.

Jacobides, M.G. (2007). The inherent limits of organizational structure and the unfulfilled role of hierarchy: Lessons from a near-war. Organization Science, 18(3), 455-477.

Kim, G. (2003). Ten Steps to Intranet Success. Online, 27(1), 66-69.

Kostopoulos, K., Papalexandris, A., Papachroni, M., \& Ioannou, G. (2011). Absorptive capacity, innovation, and financial performance. Journal of Business Research, 64, 1335-1343.

Kumar, A.J., \& Ganesh, L.S. (2009). Research on knowledge transfer in organizations: A morphology. Journal of Knowledge Management, 13(4), 161-174.

Industrija, Vol.44, No.3, 2016 
Radovanović N., Matović D.: Organizational forms and knowledge absorption

Lawrence, P.R., \& Lorsch, J.W. (1967). Organization and environment. Boston: Harvard University.

Levi-Jakšić, M., Radovanović, N., \& Radojčić, Z. (2013). Absorptive Capacity Constituents in Knowledge-Intensive Industries in Serbia, Proceedings of Rijeka Faculty of Economics. Journal of Economics and Business, 31(2), 253-278.

Levi-Jakšić, M., Marinković, S., \& Petković, J. (2011). Menadžment inovacija $i$ tehnološkog razvoja. Beograd: Fakultet organizacionih nauka.

Levinson, N.S., \& Asahi, M. (1995). Cross-national alliances and interorganizational learning. Organizational Dynamics, 24(2), 50-63.

Ferreras-Méndez, J.L., Newell, S., Fernández-Mesa, A., \& Alegre, J. (2015). Depth and breadth of external knowledge search and performance: The mediating role of absorptive capacity. Industrial Marketing Management, 47, 86-97.

Miles, R.E., \& Snow, C.C. (1986). Organizations: New concepts for new forms. California Management Review, 27, 62-73.

Nevis, E.C., Dibella, A.J., \& Gould, J.M. (1995). Understanding organizations as learning systems. Sloan Management Review, 36, 73-85.

Pugh, D.S. (1990). Organization Theory: Selected Readings. Harmondsworth: Penguin.

Radovanović, N. (2012). Intranet and its li<nfluence on absorptive capacity of organizations. In: Proceedings of the 13th International Symposium SymOrg, Innovative Management and Business Performance. Zlatibor, Serbia: Faculty of organizational sciences.1059-1065.

Senapathi, R. (2011). Dissemination and utilisation of knowledge. SCMS Journal of Indian Management, 8(2), 85-105.

Teece, D.J., Pisano, G., \& Shuen, A. (1997). Dynamic capabilities and strategic management. Strategic Management Journal, 18, 509-533.

Thompson, G.N., Estabrooks, C.A., \& Degner, L.F. (2006). Clarifying the concepts in knowledge transfer: A literature review. J Adv Nurs, 53(6), 691-701. pmid:16553677. doi:10.1111/j.1365-2648.2006.03775.x

Tu, Q., Vonderembse, M., Ragu-Nathan, T., \& Sharkey, T. (2006). Absorptive capacity: Enhancing the assimilation of time-based manufacturing practices. Journal of Operations Management, 24, 692-710.

van den Bosch, F.A.J., Volberda, H.W., \& de Boer, M. (1999). Coevolution of Firm Absorptive Capacity and Knowledge Environment: Organizational Forms and Combinative Capabilities. Organization Science, 10, 551-568. Focused Issue: Coevolution of Strategy and New Organizational Forms.

Volberda, H.W. (1998). Building the Flexible Firm: How to Remain Competitive. Oxford: Oxford University Press.

Wang, J. (2016). Knowledge creation in collaboration networks: Effects of tie configuration. Research Policy, 45, 68-80.

Wellman, J. (2009). Organizational learning: How companies and institutions manage and apply knowledge. NY: Palgrave, Macmillan.

Winkelbach, A., \& Walter, A. (2015). Complex technological knowledge and value creation in science-to-industry technology transfer projects: The moderating effect of absorptive capacity. Industrial Marketing Management, 47, 98-108.

Zahra, S.A., \& George, G. (2002). Absorptive capacity: A review, reconceptualization, and extension. Academy of Management Review, 27(2), 185-203. 